\title{
Are Audits of Financial Statements Born Unequal?
}

\author{
Manh Dung Tran ${ }^{1}$, Van Anh Doan ${ }^{2}$, Thi Thuy Bui ${ }^{3} \&$ Manh Cuong Nguyen ${ }^{4}$ \\ ${ }^{1}$ National Economics University, Vietnam \\ ${ }^{2}$ Thuong Mai University, Vietnam \\ ${ }^{3}$ Banking Academy, Vietnam \\ ${ }^{4}$ State Audit of Vietnam, Vietnam \\ Correspondence: Manh Dung Tran, Room No. 202, A14, Living quarter of National Economics University, Hai \\ Ba Trung District, Hanoi, Vietnam. Tel: 94-7120-510.
}

Received: October 16, 2017

Accepted: November 1, 2017 Online Published: November 3, 2017

doi:10.20849/abr.v2i3.209

URL: https://doi.org/10.20849/abr.v2i3.209

\begin{abstract}
Audit is getting more and more importance in assuring the reliability of financial information including financial statements for all parties. Commonly, quality of an audit is viewed as probability that financial reports are free from material irregularities. In the previous literature, there is a positive relationship between size of audit firm and audit quality that has long been understood. This has resulted in many publications to gather evidence of differential audit quality relating to audit firm size. In consequence, the conclusion has been focused that bigger audit firms produce higher audit quality than smaller ones. However, the collapse of many big international audit firms, typically Arthur Andersen has reduced the statement that large audit firms have higher audit quality than small ones. Therefore, this study looks into audit quality basing on the extent of compliance with disclosure requirements pertaining to goodwill impairment of large listed firms in Hong Kong context in the second year transition to IFRS. We found that audit firm identity appears to be a substantial variation, in which compliance levels changed significantly among auditors in the context of Hong Kong.
\end{abstract}

Keywords: audit quality, HKAS 36, impairment testing, Hong Kong.

\section{Introduction}

Quality of an audit is viewed as one of the most important issues in the audit activities and is defined as probability that financial statements are fairly presented and disclosed when an unqualified opinion is given (Kit, 2005; Simunic, 2003). The acceptance of big audit firm associated with high audit quality for a long passage of time is given in a huge literature (Krishnan \& Schauer, 2000; Simunic, 2003). However, that view is much influenced by bankruptcy of Enron, Worldcom and Andersen collapse in the 2002. This makes users of financial statements have different views of audit quality of financial services and non financial services.

In order to have high audit quality, material irregularities should be detected basing on technical competence of auditor and reported basing on auditor independence. However, it is not easy to see clearly the call of technical competence and independence. How to quantify competence and independent is too challenging in accounting and auditing field. So it makes audit quality more complicated and difficult to evaluate on the side of financial statement users and even auditors as well.

A large number of countries and territories, including Hong Kong, switched to International Financial Reporting Standards (IFRS) based financial reporting framework. Adoption of IFRS views as the most revolutionary financial reporting development and makes very difficult for financial statement preparers and also difficult for very auditors as well (Hoogendoorn, 2006).

For the harmonization and convergence of IFRS, Hong Kong has designed an own version of accounting framework, i.e. Hong Kong Financial Reporting Standards (HKFRS), that came into effect from $1^{\text {st }}$ January 2005. Because of over-complexity and challenged requirements in HKFRS, there is a high possibility to have inherent misstatements in the financial statements of reporting firms in the early years after HKFRS implementation. So, this also makes more difficult for an auditor to detect material misstatements including fraud and errors in a client's business and accounting system. Because of this, quality of an audit may be influenced in these circumstances together with combination of increased market, regulatory and technical pressures, that all have 
some implications for variation in audit quality of financial statements.

Impairment of assets including goodwill impairment and its disclosure is one of the most difficult issues in practices. Preparation of financial statements aligning with the requirements of HKAS 36 "Impairment of Assets" requires reporting firms to apply some financial principles drawn from discounting, forecasting and valuating models under potentially uncertain conditions and events in the future. With different subjective assumptions relating on future cash flows, discount rates, growth rates and forecast periods produce different outcomes of present values (using value in use method) that are discounted from future cash flows and to evaluate which is the best result is too complicated and potential controversy in the world.

Because audit quality of financial statements conducted by independent audit firms is likely to be positively related with compliance with accounting standards \& regulations (Copley et al., 1994), variations in disclosure of goodwill impairment testing regime in practice are likely to be the result of variations in quality of an audit. Thus, the audit quality measurement employed in this paper is the extent of compliance with requirements of HKAS 36. So the extent of technical compliance with disclosure requirements views as a surrogate for audit quality relating to challenged and over complicated provisions of the goodwill impairment testing regime.

\section{Literature Review}

Quality of an audit of financial reports is an important phenomenon of corporate governance can be understood as the probability that an auditor detects and reports material irregularities during the course of an audit of financial statements of auditee.

There is a fact that audit quality of financial statements is not public information and cannot be directly seen by financial statement users. So, evaluating it is one of the most controversial issues that many scientists have investigated. Auditor size is one of the most frequent item employed as a proxy for audit quality of financial reports in previous studies. Much empirical evidence is ostensibly consistent with large audit firms provide better audit quality than small ones.

Consistent with the given assumption that large audit firms provide higher audit quality. Capital market publications have shown that stock market reacts more strongly when a client shifts to a big audit firm and reports higher earnings response coefficients in comparison with client of a non big auditor. Other studies on the market reaction to the initial public offerings (IPO) of stocks experience less under-pricing from a big audit firm client than that from a non big audit firm client (Firth \& Smith, 1992).

According to Krishnan \& Schauer (2000), compliance levels of GAAP reporting requirements of big audit firm clients are higher than that of non big audit firm clients and propose that extent of compliance with GAAP is likely to be concerned to the probability of detecting material misstatements.

More and more other huge literature also provides much empirical evidence for assuring that auditor size is a proxy for audit quality of financial statements. However, events of the bankruptcies of Enron, Worldcom and others, and the related collapse of many large audit firms, typically Anderson have both reduced the good images of audit industry and confidence of financial statements users in audit quality.

As a result, to some extent, this fact has reduced the assertion that has been prevailing for a long time that large audit firms provide higher audit quality. Thus, a small number of recent researches have begun to investigate the possibility of differential audit quality among big 4 auditors, rather than supposing that there is a homogeneous audit quality among big 4 auditors.

Whereas audit quality literature is propensity to support the proposition that audit quality of financial statements conducted by large audit firms exceeds that conducted by small audit firms, there is a little evidence to show audit quality variation among big audit firms. The evaluation of audit quality on an indirect method tends to stem from a process of comparing observed values for some accepted surrogates for quality among audit firms.

Majority of literature measure indirect method based audit quality (via surrogate), including literature providing some evidence of fees (Copley, 1991; Moize, 1997), litigation and resolution (Palmrose, 1988), earning forecast accuracy (Behn et al., 2008), earnings response coefficients (Teoh \& Wong, 1993), earnings management (Becker et al., 1998), users' perceptions (Boon, 2007).

The issue of audit quality variations among large audit firms as well as large audit firms vs. non big audit firms seems very crucial and needs to be answered. Some studies conducted by Laili and Khairil (2013), Carlin et al. (2010) and others investigated the audit quality differences in different jurisdictions and found the big variations among auditors. The question is that in the context of Hong Kong, the result is the same or difference. Moreover, in countries where implementation of IFRS based reporting framework has coincided with other types of structural shifts impacting much on audit services, substantial emphasis has been directed toward auditors 
(Carlin et al., 2009). So the adoption of IFRS represents a good point to be looked into, in which goodwill impairment is the one of the most difficult issues in practice (Hoogendoorn, 2006; Tran, 2011).

\section{Data Collection and Research Methodology}

Hong Kong Financial Reporting Standards form compulsory legal frameworks for all listed reporting firms to apply on or after $1^{\text {st }}$ January 2005. In this study, data from the second year to adopt HKFRS, including HKAS 36 have been collected and used for evaluating the changes of audit quality of financial statements through a surrogate of compliance levels with disclosure requirements of goodwill impairment testing regime.

In designing the final sample, a number of steps were conducted. First, firms were required to be the members in Hong Kong Stock Exchange (HKEx) and of the second year implementation of IFRS. As a result, there were 975 firms with total market capitalisation of $\$ 13,248$ billion at the year end. Then 500 biggest market value firms with $\$ 13,131$ billion (making up $99.10 \%$ of total market capitalisation) were chosen. 251 firms were excluded because of no having goodwill as comprising an element of their asset base in the financial statements. As a result, this process designed a commencing sample of 249 firms with market value of $\$ 8,349$ billion, representing $63.02 \%$ of total market value in HKEx at the end of the second year adoption of IFRS in financial reporting.

The aim of this study is to evaluate audit quality variation among auditors based on the reporting firms' compliance with disclosure requirements pertaining to goodwill impairment so different currencies used in the annual reports reported by listed firms are accepted for inspection. The reason for accepting various currencies is that the nature of this research focuses much on compliance levels of reporting firms bearing on methods used, cash generating unit aggregation, goodwill allocation to cash generating units (CGUs), and key assumptions of goodwill impairment rather than currencies. The percentages of firms used HK\$, Renmibi and US dollars are $70 \%, 23 \%$ and $7 \%$ of the sample, respectively. However, in order to compare the values of items in the financial statements, converting currencies other than HK\$ (US dollars and China Yuan Renmibi) into HK\$ is necessary.

For the items in the consolidated Balance Sheet which reflect the financial position of the firm at a point of time, a foreign exchange (forex) rate at the year end has been used to convert into Hong Kong dollars. For the items in the consolidated Income Statement (profit and loss account) which reflect the operational results of the firm for a period of time, so a 12 month average foreign exchange rate has been used for translating into Hong Kong dollars.

To allow for industry segmentation, all firms were allocated to one of five industry groupings comprising entities with related to business sectors, namely, Consumer Goods and Conglomerate; Financials; Telecommunications and Services; Materials and Industrial Goods; and Utilities, Energy and Construction.

For the purpose of analysis in this study, auditors are classified basing on big four auditors including Deloitte, Ernst \& Young (EY), KPMG, PricewaterhouseCoopers (PWC) and Others (non-big 4 auditors).

At the date of sampling, 249 firms included in the final sample have asset values of $\$ 23,499$ billion, which contained goodwill of $\$ 503.14$ billion. An overview of the sample consists of assigned sectors; Hong Kong dollar value of firm assets and dollar value of goodwill within each sector are presented in Table 1, below.

Table 1. Overview of research sample

\begin{tabular}{lllll}
\hline Sectors & $\begin{array}{l}\text { Number } \\
\text { of firms }\end{array}$ & $\begin{array}{l}\text { Total } \\
\text { Assets } \\
\text { (\$ million) }\end{array}$ & $\begin{array}{l}\text { Total } \\
\text { Goodwill } \\
\text { (\$ million) }\end{array}$ & $\begin{array}{l}\text { Goodwill } \\
\text { as \% of Total } \\
\text { Assets }\end{array}$ \\
\hline Consumer Goods \& Conglomerate & 73 & $1,681,901.57$ & $48,126.74$ & $2.86 \%$ \\
Materials \& Industrial Goods & 29 & $355,909.88$ & $8,030.36$ & $2.26 \%$ \\
Financials & 24 & $18,193,042.36$ & $315,987.65$ & $1.74 \%$ \\
Telecommunication \& Services & 69 & $1,466,073.11$ & $100,844.18$ & $6.88 \%$ \\
Utilities, Energy \& Construction & 54 & $1,802,324.44$ & $30,170.62$ & $1.67 \%$ \\
& & & & \\
TOTAL (n) & $\mathbf{2 4 9}$ & $\mathbf{2 3 , 4 9 9 , 2 5 1 . 3 6}$ & $\mathbf{5 0 3 , 1 5 9 . 5 5}$ & $\mathbf{2 . 1 4 \%}$ \\
& & & & \\
\hline
\end{tabular}

Table 2 shows the number of firms audited by auditors, and by sectors. The number of clients for each auditor is 
uneven, with PWC dominating at $28.9 \%$ of the firms in the sample, followed by Deloitte, EY, and KPMG at $26.9 \%, 20.5 \%$ and $12.5 \%$, respectively, and other auditors with minimal share of $11.2 \%$ in the sample.

Table 2. Number of firms audited by sectors

\begin{tabular}{lllllll} 
Sectors & No. of firms & Deloitte & EY & KPMG & PWC & Others \\
\hline Consumer Goods \& Conglomerate & 73 & 22 & 18 & 5 & 17 & 11 \\
Materials \& Industrial Goods & 29 & 11 & 7 & 4 & 5 & 2 \\
Financials & 24 & 6 & 7 & 8 & 3 & - \\
Telecommunication \& Services & 69 & 11 & 10 & 7 & 30 & 11 \\
Utilities, Energy \& Construction & 54 & 17 & 9 & 7 & 17 & 4 \\
& & & & & & $\mathbf{2 8}$ \\
TOTAL (n) & $\mathbf{2 4 9}$ & $\mathbf{6 7}$ & $\mathbf{5 1}$ & $\mathbf{3 1}$ & $\mathbf{7 2}$ & $\mathbf{2 8}$ \\
& & & & & & \\
\hline
\end{tabular}

An important question is the extent to which the clients of audit firms align with over complex technical provisions of a new and challenged standard during the course of financial statement audit. Potential interests of CGU issue, discount rate and growth rate disclosures should be investigated under HKAS 36.

Consistent with Carlin et al.(2009), six techniques were employed to the sample, as below:

First, sample firms were sorted by audit firm, according to whether they employed a value in use method to estimation of CGU recoverable amount, a fair value less costs to sell method, a combination of methods (i.e. the use of value in use in some CGUs and use of fair value in others), or failed to report method disclosure. This data supported the development of insight into compliance level with basic disclosure requirements stipulated in HKAS 36.

Second, the firms in the research sample were classified by audit firm identity, according to whether they allocated all goodwill values to the specified CGUs, or whether they allocated partially goodwill values to CGUs, or whether their disclosures were not given so it was impossible to determine how or if value of goodwill had been allocated to defined CGUs. It is a basic requirement that for the purpose of impairment testing, goodwill should be allocated to each of CGUs or groups of CGUs that are expected to benefit from the synergies of the combination. So this data help financial users have insights into the compliance level with basic disclosure requirement prescribed in HKAS 36.

Third, the sample firms were filtered by audit firm, according to the relationship between the number of CGUs specified for the purpose of goodwill impairment testing and the number of business segments for the purpose of segment information reporting. So this data provides evidence of appropriate CGU aggregation on the part of reporting firms.

Fourth, the firms in the sample were classified by audit firm, according to calculated ratio of CGUs to business segments. This data provides more evidence of CGU aggregation on the part of reporting firms and combines with procedure prescribed in the third step for assuring whether CGU aggregation is appropriate.

Fifth, the sample firms were sorted by audit firm, according to the quality of discount rate disclosure in the goodwill impairment testing process. Data was stratified into four types, namely, multiple discount rates, single discount rate, range of discount rates and no effective disclosure. Firms categorized in the first category appeared to fully comply with the disclosure requirements of HKAS 36 by disclosing unique rates applicable to each of their various CGUs. This type of disclosure fully complies with the standard requirements and provides a higher assurance of process quality through different discount rates to each specified CGU.

Firms in the second category, i.e. "single discount rate", showed that they defined blanket whole of firm discount rate for all specified CGUs for measuring CGU recoverable amount in the discounted cash flow model. This did not appear to comply with the requirements that a discount rate unique to each specified CGU and each CGU risk was arguably different. 
Firms were sticked in the third category disclosed a range of discount rates which had been employed for estimating CGU recoverable amount. Because of lacking specific discount rate to each specified CGU, it is questionable whether disclosure of this category meets the requirements of HKAS 36.

Finally, allocation of firms in the fourth category signified that the firms failed to provide inadequate discount rate disclosure, and in consequence provided no meaningful information for financial statement users to evaluate the robustness of goodwill impairment testing process. Therefore, these firms were judged to have poor disclosures and not to comply with the disclosure requirements of HKAS 36.

Sixth, the sample firms were filtered by audit firm, according to the quality of growth rate disclosure in the regime of goodwill impairment testing. Data was stratified according to a very similar taxonomy to that described bearing on discount rates, i.e. multiple growth rates, single growth rate, range of growth rates and no effective disclosure. The first category represented the highest level of disclosure, the fourth the poorest.

\section{Results and Discussion}

The interest of this paper concentrates on variation of audit quality among auditors based on the reporting firms' compliance with disclosure requirements bearing on goodwill impairment under HKAS 36. The first issue in understanding the process of goodwill impairment testing is the selection of valuation method for measuring recoverable amount of assets assigned to CGUs.

Under HKAS 36, recoverable amount of an asset or a CGU is the greater of its fair value less costs to sell, determined basing on market based evidence, and its value in use, determined basing on a discounted cash flow model. Table 3 shows the frequency of approach used for estimating recoverable amount of an asset or a CGU, either fair value or value in use or mixed method (combination of the fair value and value in use), and no effective disclosure.

The data denotes that the dominant approach to the estimation of recoverable amount was the approach of value in use. A total of 213 firms (accounting for 85.5\% of the sample) employed this method as the exclusive basis for determining CGU recoverable amount. Only 6 firms chose fair value as the sole basis for estimating CGU recoverable amount. A further 10 instances disclosed that they applied a mixed method (employed value in use in some CGUs and fair value in others).

Up to 20 cases (about $8 \%$ of final sample) failed to report method employed for determining CGU recoverable amount. Specifically, clients of other audit firms provided no effective information relating to method used with highest percentage of $10.7 \%$. Followed by clients of EY, PWC and Deloitte were at $9.8 \%, 8.3 \%$ and $7.5 \%$, respectively, and with clients of KPMG at lowest percentage in total, about $3.2 \%$.

Table 3. Approach adopted to determine recoverable amount of CGUs

\begin{tabular}{|c|c|c|c|c|c|c|}
\hline Approach Used & $\begin{array}{l}\text { Deloitte } \\
n=67\end{array}$ & $\begin{array}{l}\mathbf{E Y} \\
\mathrm{n}=51\end{array}$ & $\begin{array}{l}\text { KPMG } \\
\mathrm{n}=31\end{array}$ & $\begin{array}{l}\text { PWC } \\
n=72\end{array}$ & $\begin{array}{l}\text { Others } \\
n=28\end{array}$ & $\begin{array}{l}\text { Total } \\
\mathrm{n}=249\end{array}$ \\
\hline No effective disclosure & 5 & 5 & 1 & 6 & 3 & 20 \\
\hline Fair value & 1 & 2 & 2 & - & 1 & 6 \\
\hline Value-in-use & 58 & 42 & 28 & 61 & 24 & 213 \\
\hline Mixed method & 3 & 2 & - & 5 & - & 10 \\
\hline $\begin{array}{l}\text { Proportions of firms where no } \\
\text { effective disclosure }\end{array}$ & $7.5 \%$ & $9.8 \%$ & $3.2 \%$ & $8.3 \%$ & $10.7 \%$ & $8.0 \%$ \\
\hline
\end{tabular}

Under the requirements of HKAS 36, goodwill balance is subject to an impairment testing. Even if, whether the value of goodwill are immaterial compared with the values on the balance sheet. So the firms with failure of disclosing method used were judged not to comply with the disclosure requirements of the HKAS 36 . However, based on only this analysis, it is not possible to reach robust conclusion as to possible variation in quality by 
audit firm.

The next analytical tool adopted was to compare the reported value of goodwill on the financial reports with the sum of the amounts of goodwill allocated to defined CGUs of reporting firms. As presented in Table 4, the majority of firms fully complied with the disclosure requirements, accounting for $71.9 \%$ of the total sample (in case of it was possible to have matched data between value of goodwill on the balance sheet and the sum of goodwill allocated to CGUs). Only two cases belonging to client of EY and KPMG that goodwill value did not allocate completely to specified CGUs and discrepancies between goodwill value and the sum of goodwill allocated to CGU were immaterial.

There have been 68 cases (about 27.3\% of the final sample) provided no effective disclosure relating to goodwill allocation to defined CGUs. Clients of PWC failed to disclose the effective disclosure pertaining to goodwill allocation to CGUs with highest percentage of $37.5 \%$. Followed by clients of EY, KPMG, other auditors were at $31.4 \%, 25.8 \%$ and $25 \%$, respectively, and with clients of Deloitte at lowest percentage in total, about $15 \%$.

Table 4: Compliance of CGU allocation by auditors

\begin{tabular}{lllllll}
\hline Levels of Compliance & $\begin{array}{l}\text { Deloitte } \\
\mathrm{n}=67\end{array}$ & $\begin{array}{l}\text { EY } \\
\mathrm{n}=51\end{array}$ & $\begin{array}{l}\text { KPMG } \\
\mathrm{n}=31\end{array}$ & $\begin{array}{l}\text { PWC } \\
\mathrm{n}=72\end{array}$ & $\begin{array}{l}\text { Others } \\
\mathrm{n}=28\end{array}$ & $\begin{array}{l}\text { Total } \\
\mathrm{n}=249\end{array}$ \\
\hline Non-compliance & 10 & 16 & 8 & 27 & 7 & 68 \\
Fully compliance & 57 & 34 & 22 & 45 & 21 & 179 \\
Ostensibly compliance & - & 1 & 1 & - & - & 2 \\
& & & & & & \\
\hline
\end{tabular}

From an audit firm identity, there was little evidence of cross sectional variation in practice. In the first two analytical procedures applied to the sample data, however, it appeared that Deloitte's clients had the lowest percentage of noncompliance levels, whereas clients of remaining auditors had insignificant variation of non-compliance levels with the accounting standard. The next analysis procedure produces more evidence of compliance levels of audit firm clients relating to CGU aggregation, which is set out in the next table.

Table 5 reveals that clients of non big 4 auditors have a greater tendency to define fewer CGUs than business segments or report no meaningful disclosure of CGU definition than clients of big 4 firms, especially PWC. Under HKAS 36, each CGU or groups of CGUs to which the goodwill is so allocated will present the lowest level within the entity, and not be larger than a segment of the firm. So, clients of all audit firms violated the provision with different levels.

The data show that about $82 \%$ of other auditors specified fewer CGUs than business segments or provided no effective disclosure relating to relationship between number of CGUs and number of business segments. In contrast, this happened in only $62.5 \%$ of PWC clients, with EY, KPMG and Deloitte clients at about $80 \%, 71 \%$ and $69 \%$, respectively. This suggests a higher risk of CGU aggregation belonging to non big audit 4 clients than that in clients of Big 4 firms, especially PWC. 
Table 5. Relationship between CGU \& business segments by auditors

\begin{tabular}{llllll}
\hline Number of firms & $\begin{array}{l}\text { Deloitte } \\
\mathrm{n}=67\end{array}$ & $\begin{array}{l}\text { EY } \\
\mathrm{n}=51\end{array}$ & $\begin{array}{l}\text { KPMG } \\
\mathrm{n}=31\end{array}$ & $\begin{array}{l}\text { PWC } \\
\mathrm{n}=72\end{array}$ & $\begin{array}{l}\text { Others } \\
\mathrm{n}=28\end{array}$ \\
\hline & 10 & 14 & 8 & 24 & 7 \\
No Effective Disclosure & 10 & 4 & 6 & 8 & 1 \\
$\mathrm{CGU}>$ Segments & 11 & 6 & 3 & 19 & 4 \\
$\mathrm{CGU}=$ Segments & 36 & 27 & 14 & 21 & 16 \\
$\mathrm{CGU}<$ Segments & & & & & \\
$\quad$ & & & & & \\
$\begin{array}{l}\text { Proportion of firms where CGUs }<\text { segments } \\
\text { or no effective disclosure }\end{array}$ & $68.7 \%$ & $80.4 \%$ & $71.0 \%$ & $62.5 \%$ & $82.1 \%$ \\
& & & & & \\
\hline
\end{tabular}

Other technique of analytical procedure is used for identifying audit firm pertaining to the quality of discount rate disclosure for estimating CGU recoverable amount. As shown in Table 6, clients of PWC emerged to provide less effective disclosure pertaining to discount rates than clients of remaining big 4 auditors and non big auditors, particularly Deloitte.

The data also show that clients of audit firms employed unusually low discount rates. Specifically, Deloitte clients adopted a rate of $3.8 \%$, through to clients of EY at $4 \%, \mathrm{KPMG}$ clients at $4.2 \%$, PWC clients at $4.5 \%$ and other audit firm clients at $5.50 \%$. Applying lower mean discount rates in the model of discounted cash flow would result in overestimating present values (recoverable amounts), and consequently reduce the chance to recognize impairment expenses in the accounting period, and to increase accounting profit recognized in the consolidated financial statements.

Table 6. Discount rates adopted for testing impairment of CGUs

\begin{tabular}{|c|c|c|c|c|c|}
\hline Discount Rate Disclosures & $\begin{array}{l}\text { Deloitte } \\
n=61\end{array}$ & $\begin{array}{l}\text { EY } \\
\mathrm{n}=44\end{array}$ & $\begin{array}{l}\text { KPMG } \\
\mathrm{n}=28\end{array}$ & $\begin{array}{l}\text { PWC } \\
n=66\end{array}$ & $\begin{array}{l}\text { Others } \\
n=24\end{array}$ \\
\hline No disclosure $(\mathrm{n}=37)$ & 2 & 5 & 5 & 23 & 2 \\
\hline Multiple explicit discount rate $(\mathrm{n}=24)$ & 7 & 5 & 3 & 7 & 2 \\
\hline Single explicit discount rate $(\mathrm{n}=148)$ & 47 & 31 & 18 & 34 & 18 \\
\hline Range of discount rates $(n=14)$ & 5 & 3 & 2 & 2 & 2 \\
\hline Proportion of firms where no disclosure & $3.3 \%$ & $11.4 \%$ & $17.9 \%$ & $34.8 \%$ & $8.3 \%$ \\
\hline Minimum discount rate & $3.80 \%$ & $4.00 \%$ & $4.20 \%$ & $4.50 \%$ & $5.50 \%$ \\
\hline Maximum discount rate & $23.50 \%$ & $25.00 \%$ & $25.80 \%$ & $17.93 \%$ & $23.13 \%$ \\
\hline Mean discount rate & $9.55 \%$ & $9.56 \%$ & $9.96 \%$ & $9.77 \%$ & $11.20 \%$ \\
\hline
\end{tabular}


A scrutiny of data to growth rates employed in the discounted cash flow model for estimating recoverable amount of each CGU. Table 7 illustrates a different pattern in comparison with the pattern shown in the discount rate disclosure in practice. Highest percentage of non-compliance level with the disclosure requirements belongs to clients of Deloitte, accounting for $80.3 \%$. Followed by clients of other auditors, PWC, EY and KPMG were at about $75 \%, 71.2 \%, 68.2 \%$ and $57.1 \%$, respectively.

Average estimated growth rates used by other auditor clients (about $4.3 \%$ ) were higher than that chosen by big 4 auditor clients, particularly Deloitte (about $2.5 \%$ ). By using higher growth rates in the model of discounted cash flow, other things being equal, would increase the determined recoverable amount of CGU assets, and reduce the chance of recognizing goodwill impairment charges, and increase the possibility of reporting accounting profit in a given year.

Table 7. Growth rates adopted for testing impairment of CGUs

\begin{tabular}{|c|c|c|c|c|c|}
\hline Growth Rate Disclosures & $\begin{array}{l}\text { Deloitte } \\
n=61\end{array}$ & $\begin{array}{l}\text { EY } \\
n=44\end{array}$ & $\begin{array}{l}\text { KPMG } \\
\mathrm{n}=28\end{array}$ & $\begin{array}{l}\text { PWC } \\
n=66\end{array}$ & $\begin{array}{l}\text { Others } \\
n=24\end{array}$ \\
\hline No disclosure $(\mathrm{n}=160)$ & 49 & 30 & 16 & 47 & 18 \\
\hline Multiple explicit growth rate $(\mathrm{n}=13)$ & 1 & 3 & 3 & 6 & 0 \\
\hline Single explicit growth rate $(n=42)$ & 10 & 10 & 8 & 9 & 5 \\
\hline Range of growth rates $(\mathrm{n}=8)$ & 1 & 1 & 1 & 4 & 1 \\
\hline Proportion of firms where no disclosure & $80.3 \%$ & $68.2 \%$ & $57.1 \%$ & $71.2 \%$ & $75.0 \%$ \\
\hline Minimum growth rate & $-1.00 \%$ & $0.00 \%$ & $0.00 \%$ & $0.00 \%$ & $2.00 \%$ \\
\hline Maximum growth rate & $9.00 \%$ & $14.00 \%$ & $6.54 \%$ & $20.00 \%$ & $7.00 \%$ \\
\hline Mean growth rate & $2.54 \%$ & $3.11 \%$ & $3.32 \%$ & $3.47 \%$ & $4.30 \%$ \\
\hline
\end{tabular}

\section{Conclusion}

This research is conducted for accumulating evidence which might show variation in audit quality among auditors (Deloitte, EY, KPMG, PWC and non big 4 auditors) during the course of financial statement audit including audit of goodwill impairment. The approach employed in this research focussed on the nature and quality of disclosures pertaining to goodwill impairment testing regime under the accounting standard of "Impairment of Assets".

Basing on evidence collected from listed firms for the second year after HKFRS adoption. By testing the approach employed, CGU aggregation and variables of discount rates and growth rates, it appears that the systematically noncompliance levels in relation to goodwill impairment were on the part of clients of all audit firms. In which, clients of non Big 4 auditor have higher non compliance levels than clients of big 4 audit firms do.

Out of big 4 audit firms, clients of Deloitte were judged, in general, to be the best practice disclosure of goodwill impairment. Meanwhile, clients of EY, KPMG, and PWC were evaluated to have significant variations of practice disclosures pertaining to approach implemented, CGU aggregation and discount rates and growth rates. Interestingly, all financial statements of listed firms in the final sample were stated truly and fairly in all material respects on the eyes of independent auditors including big 4 auditors. So it raised the issue that quality of financial statement audit is really questionable in the context of Hong Kong.

Clearly, the extent of compliance with HKFRS including HKAS 36 is likely to be related to the probability of detecting and reporting material irregularities during the course of financial statement audit of listed firms in the context of Hong Kong where accounting framework is evaluated fairly well. Changes in disclosure of goodwill 
impairment of audit firm clients are likely to be the result of quality variations of financial statement audit. So evidence got in this study supports the viewpoint that audit quality of big 4 audit firms is regarded to be higher than that of non big 4 auditors and audit quality among big 4 auditors is not equal, but is unequal. Further research on variations in audit quality of financial statements among audit firms when compliance of goodwill impairment in the time series and legal framework improved are identified and discussed.

\section{References}

Behn, B. K., Choi, J.-H., \& Kang, T., (2008). Audit Quality and Properties of Analyst Earnings Forecast. The Accounting Review, 83(2), 327-349.

Boon, K. (2007). Compulsory Audit Tendering and Audit Quality: Evidence from Australian Local Government. Macquarie University.

Caneghem, T. V. (2004). The Impact of Audit Quality on Earnings Rounding-up Behaviour: Some U.K. Evidence. European Accounting Review, 13(4), 771-786.

Carlin, T. M., Finch, N. \& Laili, N. H. (2009). Investigating audit quality among Big 4 Malaysian firms. Asian Review of Accounting, 17(2), 96-114.

Carlin, T M., Finch, N, \& Khairil, F K. (2010). Singapore Audit Quality and the Complexity of FRS 36 Disclosures Requirements. International Review of Business Research Papers, 6(2), 81-94.

Colbert, G., \& Murray, D. (1998). The Association between Auditor Quality and Auditor Size: An Analysis of Small CPA Firms. Journal of Accounting, Auditing \& Finance, 135-150.

Copley, P. A. (1991). The Association between Municipal Disclosure Practices and Audit Quality. Journal of Accounting and Public Policy, 10(4), 245-266.

Copley, P. A., Doucet, M. S., \& Gaver, K. M. (1994). A Simultaneous Equations Analysis of Quality Control Review Outcomes and Engagement Fees for Audit of Recipients of Federal Financial Assistance. The Accounting Review, 69(1), 244-256.

Deangelo, L. E. (1981). Audit Size and Audit Quality. Journal of Accounting and Economics, 3, 183-199.

Firth, M., \& Smith, A. (1992). Selection of Auditor Firms by Companies in the New Issue Market. Applied Economics, 24, 247-255.

Firth, M., \& Smith, A. (1992). Selection of Auditor Firms by Companies in the New Issue Market. Applied Economics, 24, 247-255.

Hoogendoorn, M. (2006). International Accounting Regulation and IFRS Implementation in Europe and Beyond - Experiences with First-time Adoption in Europe. Accounting in Europe, 3.

Icaew. (2005). Audit Quality. The Institute of Chartered Accountants in England and Wales.

Kit, F. Y. (2005). Evidence of Audit Quality Differences among Big Five Auditors: An Empirical Study. City University of Hong Kong,

Krishnan, J., \& Schauer, P. C. (2000). The Differentiation of Quality among Auditors: Evidence from the Not-for-Profit Sector. Auditing: A Journal of Practice \& Theory, 19(2), 9-25.

Laili, N.H., \& Khairil, F.K. (2013). IFRS Compliance and Audit Quality Among Big 3 Auditors: The Case of Goodwill Impairment. Retrieved from http://papers.ssrn.com/sol3/papers. cfm?abstract_id=2358336.

Moize, P. (1997). Auditor Reputation: the International Empirical Evidence. International Journal of Auditing, $1(1), 61-74$.

Palmrose, Z.-V. (1988). An Analysis of Auditor Litigation and Audit Service Quality. The Accounting Review, 63, $55-73$.

Simunic, D. A. (2003). Audit Quality and Audit Firm Size: Revisited. The University of Bristish Columbia.

Teoh, S. H., \& Wong, T. J. (1993). Perceived Auditor Quality and the Earnings Response Coefficient. The Accounting Review, 68(2), 346-366.

Tran, M.D. (2011). Goodwill Impairment: The Case of Hong Kong. PhD Thesis, Macquarie University, Sydney, Australia.

Yu, M.D. (2007). The Effect of Big Four Office Size on Audit Quality. University of Missouri - Columbia. 


\section{Copyrights}

Copyright for this article is retained by the author(s), with first publication rights granted to the journal.

This is an open-access article distributed under the terms and conditions of the Creative Commons Attribution license (http://creativecommons.org/licenses/by/4.0/). 